\title{
Growth Parameters of DK8031 Maize Variety as Affected by Varying Irrigation and Nitrogen Fertilizer Rates in Embu County, Kenya
}

\author{
Charles Nyambane Onyari ${ }^{1}$, Antony Mwangi Kibe ${ }^{2}$ and Samuel Mwonga ${ }^{2}$ \\ 1. Department of Land and Water Management, Embu University, EMBU 6-60100, Kenya \\ 2. Department of Crops, Horticulture and Soils, Egerton University, EGERTON 536, Kenya
}

\begin{abstract}
Determination of crop growth parameters of maize helps assess the performance of the crop for food security. A study was conducted in two seasons covering 2012 and 2013 to establish optimal irrigation and nitrogen fertilizer rates for drought tolerant hybrid maize (Zea mays L.), DK8031 variety, in sandy loam soils using furrow irrigation. Four additive irrigation levels (119.05 mm, $238.10 \mathrm{~mm}, 357.15 \mathrm{~mm}$ and $476.2 \mathrm{~mm})$ were allocated the main plots while five nitrogen fertilizer rates $(0 \mathrm{~kg} / \mathrm{ha}, 60,75 \mathrm{~kg} / \mathrm{ha}, 90$ $\mathrm{kg} / \mathrm{ha}$ and $100 \mathrm{~kg} / \mathrm{ha}$ ) were allocated the sub-plots. Both irrigation and nitrogen fertilizer treatments significantly enhanced crop growth parameters under consideration. Stand count per treatment plot, plant height and number of leaves per ranged from 45-59 plants/plot, 215-238 cm and 14-16 leaves respectively. It was concluded that use of supplementary irrigation and phased nitrogen fertilizer rates for maize growing in areas such as Embu can greatly promote crop growth.
\end{abstract}

Key words: Maize, irrigation, nitrogen fertilizer rates, plant height, leaves per plant.

\section{Introduction}

Low agricultural production leads to low incomes, poor nutrition, vulnerability to risk and threat and lack of empowerment. Land degradation and soil fertility depletion are considered the major threats to food security and natural resource conservation in Sub-Saharan Africa. Investments in technology, policy and institutional reforms are needed to increase agricultural productivity, to ensure food security and sustained national economies [1]. Maize production which is the staple food for over $90 \%$ of Kenya's population and mostly produced under rainfed agricultural systems has been declining at an alarming rate leading to food insecurity [2].

Kenya's blueprint development plan identifies agriculture as the mainstay of the country's economy that currently represents $24 \%$ of the Gross Domestic Product (GDP) and accounting for $65 \%$ of Kenya's

Corresponding author: Charles Nyambane Onyari, engineer, research fields: soil fertility and water management. E-mail: onyaricharles@yahoo.com. exports and $18 \%$ of the total formal employment [3]. The current constitution of Kenya mandates the national government to be in charge of policy and the County governments to implement in areas such as crop husbandry and plant disease control. The first Medium Term Plan (MTP) identifies arid and semi-arid (ASAL) development projects as of the key flagship projects to be achieved through irrigation. The MTP envisions that agricultural research and development will be enhanced through collaboration and linkages with emphasis laid on irrigation among other agricultural developments meant to improve on national food security. The developed technologies are to be relayed to farmers and other stakeholders through holistic approach in extension service provision.

Widtose [3] defines irrigation as the artificial application of water to lands for the purpose of producing large and steady crop yields whenever the rainfall is insufficient to meet the full water requirements of crops. He notes that about $25 \%$ of the 
earth's surface receives $250 \mathrm{~mm}$ or less of rainfall annually and can only be reclaimed using irrigation, while intensive crop production for areas receiving between $250 \mathrm{~mm}$ and $500 \mathrm{~mm}$ annual rainfall require irrigation and dry-farming.

The need to be food secure worldwide receives critical priority as this determines the health and wealth of a country in the face of global warming that leads to prolonged drought and unpredictable weather patterns, declining soil fertility, ever increasing human population and limited natural resource base. Cereal grains such as maize (Zea mays L.) provide a staple source of food for many communities in the world [4].

To increase agricultural production so as to achieve economic development and attain food security in Sub-Saharan Africa, it needs to expand irrigation so as to realize full potential of water resources and irrigated agriculture $[5,6]$. This is in line with the meeting on the millennium development goals of eradicating poverty and extreme hunger without compromising on environmental sustainability [7]. They note that less than $4 \%$ of renewable water resources in Africa are currently withdrawn for agriculture. Barriers include the lack of financial and human resources to build irrigation and related rural infrastructure and acquire agricultural technology, and inadequate access to markets. Since water causes changes in the soil to the full depth to which it penetrates, then regulated irrigation can be a means of modifying soil properties for production of crops such as maize [3].

However, drought is a major constraint for plant productivity worldwide and different mechanisms of drought-tolerance have been reported for several plant tissues including maize [8]. Drought is economically and ecologically disruptive and in severe conditions profoundly impacts on agriculture, water resources, tourism, ecosystems and basic human welfare as noted by the Federal Emergency Management Agency of the Unites States of America. Climate data models indicate drought will be more frequent in future and that the likelihood of heat waves may progressively increase in intensity and frequency over the next several decades, strengthening the environmental conditions for drought and wildfire events [9]. This work recommends intensification and increased productivity of production factors, including land and water, in the context of good arable land in Kenya and the underdeveloped irrigation.

Work in India shows that most of the improved varieties of maize require 100-120 days to mature with early vegetative stage (20-40 DAS) and tasseling and silking (45-60 DAS) being critical in demand for water $[10,11]$. The author also notes that maize is very sensitive to excess water and hence, advisable to plant it on ridges or make ridges in the field after its establishment. Submergence in the soil for 3-5 days during seedling or flowering period reduces the yield considerably.

Nitrogen fertilizers are developed to supply nitrogen $(\mathrm{N})$ as the major nutrient and it is a major constituent of all cells of plant and animal origin [12]. The authors indicate nitrogen fertilizers are available in three main forms: ammonium, amide and ammonium nitrate fertilizer and they are usually applied as top dressing when plants are actively growing and the soils are moist.

The broad objective was to enhance food security and improve livelihoods of farmers through efficient utilization of irrigation water and nitrogen fertilizer.

The specific objectives are to determine the effects of irrigation levels and nitrogen fertilizer rates on the growth parameters of DK8031 maize variety.

Growth of maize comes before biomass and grain yields are obtained and proper understanding of its parameters can be used to predict these yields by maize growers. This paper examines the effect of supplemental irrigation water and nitrogen fertilizer rates on the growth of dryland hybrid maize (DK8031 variety) in two seasons during the 2012 and 2013 years. 


\section{Materials and Methods}

\subsection{Experimental Site, Soils and Weather}

Embu west district is in Embu County, part of the former eastern province, Kenya, at latitude of $3^{\circ} 30^{\prime} \mathrm{S}$, longitude of $37^{\circ} 30^{\prime} \mathrm{E}$, and altitude of $1,480 \mathrm{~m}$ above sea level.

The area receives a total annual rainfall of between $1,200 \mathrm{~mm}$ and $1,500 \mathrm{~mm}$ in two rainy seasons_- "long rains" (March to June) and "short rains" (mid October to December), with poor distribution in most areas. The mean monthly temperature ranges between $14{ }^{\circ} \mathrm{C}$ and $26{ }^{\circ} \mathrm{C}$.

The soils are mainly humic nitisols [13] derived from basic volcanic rocks [14]. They are deep, well weathered with friable clay texture with moderate to high inherent fertility.

\subsection{Experimental Design and Layout}

The experiment was laid out in a split-plot in randomized complete block design. The irrigation levels (I) formed the main plots while the nitrogen fertilizer levels (N) formed the subplots. Each treatment plot measured $4 \times 3 \mathrm{~m}$. A $1.0 \mathrm{~m}$ footpath was left between the subplots and $1.5 \mathrm{~m}$ spacing between blocks to minimize percolation effects of water and fertilizer between blocks. Treatments were allocated to the subplots, which were $1.0 \mathrm{~m}$ apart. Each subplot had rows of DK8031 maize variety having six rows each at a spacing of $75 \times 30 \mathrm{~cm}$. This gave a population of 44,444 plants/ha. A total plot area of about $1,200 \mathrm{~m}^{2}$ was used for the three blocks.

\subsection{Weather Data Collection and Graphs}

The Kenya Agricultural Research Institute (KARI), Embu, in conjunction with the local Kenya meteorological department provided the following data over the experimental period: rainfall, wind speed, daily maximum and mean temperatures, sunshine/radiation and relative humidity. The cost was met by the National Council of Science, Technology and Innovation (NACOSTI), formerly National Council of Science and Technology (NCST).

\subsection{Crop Establishment and Management}

Land was tilled to at least $20 \mathrm{~cm}$ depth and closed furrows made at $75 \mathrm{~cm}$ spacing by ridging. Two seeds per hole of DK8031 maize variety were sown at an intra-spacing of $30 \mathrm{~cm}$, giving a population rate of 44,444 plants per hectare of maize after thinning to one plant per hole for all treatment plots. At sowing time, a compound fertilizer 17:17:17 was used at a uniform rate of $60 \mathrm{Kg} \mathrm{N} / \mathrm{ha}$. The application of nitrogen fertilizer coincided with times of irrigation at two, six, ten and fourteen weeks after planting. Irrigation water was applied at rates of $119.05 \mathrm{~mm}$, $238.10 \mathrm{~mm}, 357.15 \mathrm{~mm}$ and $476.2 \mathrm{~mm}$ respectively. Manual weeding was first done four weeks after emergence and again at knee high in both seasons. Application of stalk borer dust was as per recommendations used in local agricultural practice.

\subsection{Sampling and Data Collection: Plant Height, Stand Count and Number of Leaves Per Plant}

After emergence one week after sowing, three plants per sub-plot were randomly sampled and tagged. The plant height was measured in centimeters $(\mathrm{cm})$ using a steel tape measure even as the height progressed. The mean height of the three maize plants was then later calculated and recorded for the treatment plot. Height readings were taken every two weeks till physiological maturity was determined in Days After Sowing (DAS). The plant stand count per treatment plot and the number of leaves per plant were also recorded concurrently every two weeks after sowing, using three randomly sampled plants and the means recorded for analysis. The plant growth rates were then computed and presented in tabular and graphical forms.

\subsection{Experimental Layout and Treatments}

2.6.1 Irrigation Levels

$\mathrm{I}_{1}$ : Irrigation $\left(1,190.5 \mathrm{~m}^{3} \cdot \mathrm{ha}^{-1}\right)$ at sowing; 
$\mathrm{I}_{2}: \mathrm{I}_{1}$ and then two weeks after sowing, total 2,381.0 $\mathrm{m}^{3} \cdot \mathrm{ha}^{-1}$;

$\mathrm{I}_{3}: \mathrm{I}_{2}$ then 6 weeks after sowing, total 3,570.5 $\mathrm{m}^{3} \cdot \mathrm{ha}^{-1}$;

$\mathrm{I}_{4}: \mathrm{I}_{3}$ then 10 weeks after sowing, total $4,762.0$ $\mathrm{m}^{3} \cdot \mathrm{ha}^{-1}$.

\subsubsection{Nutrient Nitrogen Fertilizer Rates}

$\mathrm{N}_{0}$ : No fertilizer application (control treatment) $=0$ $\mathrm{kg} \mathrm{N} / \mathrm{ha}$;

$\mathrm{N}_{1}$ : Compound fertilizer (17:17:17) applied at sowing at a rate of $60 \mathrm{~kg} \mathrm{~N} / \mathrm{ha}$;

$\mathrm{N}_{2}: \mathrm{N}_{1}$ with additional $15 \mathrm{~kg} \mathrm{~N} / \mathrm{ha}$ of CAN two weeks after sowing, total $=75 \mathrm{~kg} \mathrm{~N} / \mathrm{ha}$;

$\mathrm{N}_{3}: \mathrm{N}_{2}$ with additional $15 \mathrm{~kg} \mathrm{~N} / \mathrm{ha}$ of CAN 6 weeks after sowing, total $=90 \mathrm{~kg} \mathrm{~N} / \mathrm{ha}$;

$\mathrm{N}_{4}: \mathrm{N}_{3}$ with additional $15 \mathrm{~kg} \mathrm{~N} / \mathrm{ha}$ of CAN 10 weeks after sowing, total $=105 \mathrm{~kg} \mathrm{~N} / \mathrm{ha}$.

\section{Results}

\subsection{Weather Data}

The dryland hybrid maize was sown on 19th April 2012 and 13th October 2012 and harvested on 29th September 2012 and 9th March 2013, in season I and season II respectively. The data obtained from KALRO-Embu was summarized in Table 1 and Fig. 2.
3.2 Effect of Irrigation and Fertilizer Rates on Stand Count

It was observed that the stand count in Season I under varying irrigation regimes was highest at 4 Weeks After Sowing (WAS) and lowest at 10 WAS when it stabilized for the rest of the growth period (Table 2). The mean stand count of the dryland hybrid maize decreased from 53 at 2 WAS to 45 at WAS with significant differences in counts throughout the growing season. By 10 WAS, results showed that plant stand-count increased with irrigation applications and those that received four applications were significantly taller compared with treatments that were irrigated once at sowing time. This may imply that availability of sufficient water for maize growth enhances stand-count.

Treatments that had no fertilizer application had consistently lower stand-count throughout the period of growth except at 8 WAS where treatments that received only $60 \mathrm{~kg} \cdot \mathrm{ha}^{-1}$ of $\mathrm{N}$-fertilizer had the lowest stand-count (Table 2). It was observed generally that stand-count increased relatively with increasing rates of nitrogen fertilizer application. The model will explain between $74.4 \%\left(\mathrm{R}^{2}=0.744\right)$ at $10 \mathrm{WAS}$ and $84.1 \%\left(\mathrm{R}^{2}=0.841\right)$ at 4 WAS (Table 2). This showed

Table 1 Weather data for maize grown over two seasons in Embu county.

\begin{tabular}{lcllllllll}
\hline $\begin{array}{l}\text { Month (April } \\
2012 \text { to March }\end{array}$ & $\begin{array}{l}\text { Rainfall } \\
(\mathrm{mm})\end{array}$ & $\begin{array}{l}\text { Min. temp. Max. temp. Mean } \\
\left({ }^{\circ} \mathrm{C}\right)\end{array}$ & $\begin{array}{l}\left.{ }^{\circ} \mathrm{C}\right) \\
\text { temp. }\left({ }^{\circ} \mathrm{C}\right)\end{array}$ & $\begin{array}{l}\text { Wind run } \\
(\mathrm{km} / \text { day })\end{array}$ & $\begin{array}{l}\text { Rad. } \\
\left(\mathrm{MJ} \cdot \mathrm{m}^{-2}\right)\end{array}$ & $\begin{array}{l}\text { RH }(\%) \\
(06 Z)\end{array}$ & $\begin{array}{l}\text { RH }(\%) \\
(12 Z)\end{array}$ & $\begin{array}{l}\text { RH }(\%) \\
\text { mean }\end{array}$ \\
\hline April & 406.4 & 15.8 & 25.8 & 20.8 & 97.2 & 17.48 & 80 & 57 & 68.5 \\
May & 164.4 & 15.3 & 24.2 & 19.8 & 74.3 & 17.34 & 78 & 63 & 70.5 \\
June & 39.2 & 13.9 & 22.3 & 18.1 & 53.3 & 13.57 & 80 & 62 & 71.0 \\
July & 30.7 & 13.0 & 23.3 & 18.2 & 45.9 & 10.08 & 85 & 68 & 71.5 \\
August & 28.0 & 12.9 & 20.1 & 16.5 & 59.2 & 15.10 & 78 & 53 & 65.5 \\
September & 8.7 & 13.5 & 25.4 & 19.5 & 76.4 & 18.57 & 75 & 49 & 62.0 \\
October & 293.1 & 15.2 & 26.2 & 20.7 & 102.3 & 21.20 & 75 & 52 & 63.5 \\
November & 280.1 & 15.0 & 25.1 & 20.1 & 111.1 & 19.87 & 78 & 58 & 68.0 \\
December & 187.1 & 14.1 & 24.1 & 19.1 & 105.8 & 18.76 & 76 & 62 & 69.0 \\
January & 17.1 & 13.7 & 25.6 & 19.7 & 118.7 & 22.97 & 68 & 55 & 61.5 \\
February & 4.7 & 13.3 & 27.6 & 20.5 & 156.4 & 25.19 & 62 & 41 & 51.5 \\
March & 159 & 15.4 & 29.0 & 22.2 & 112.0 & 21.46 & 78 & 49 & 63.5 \\
\hline
\end{tabular}




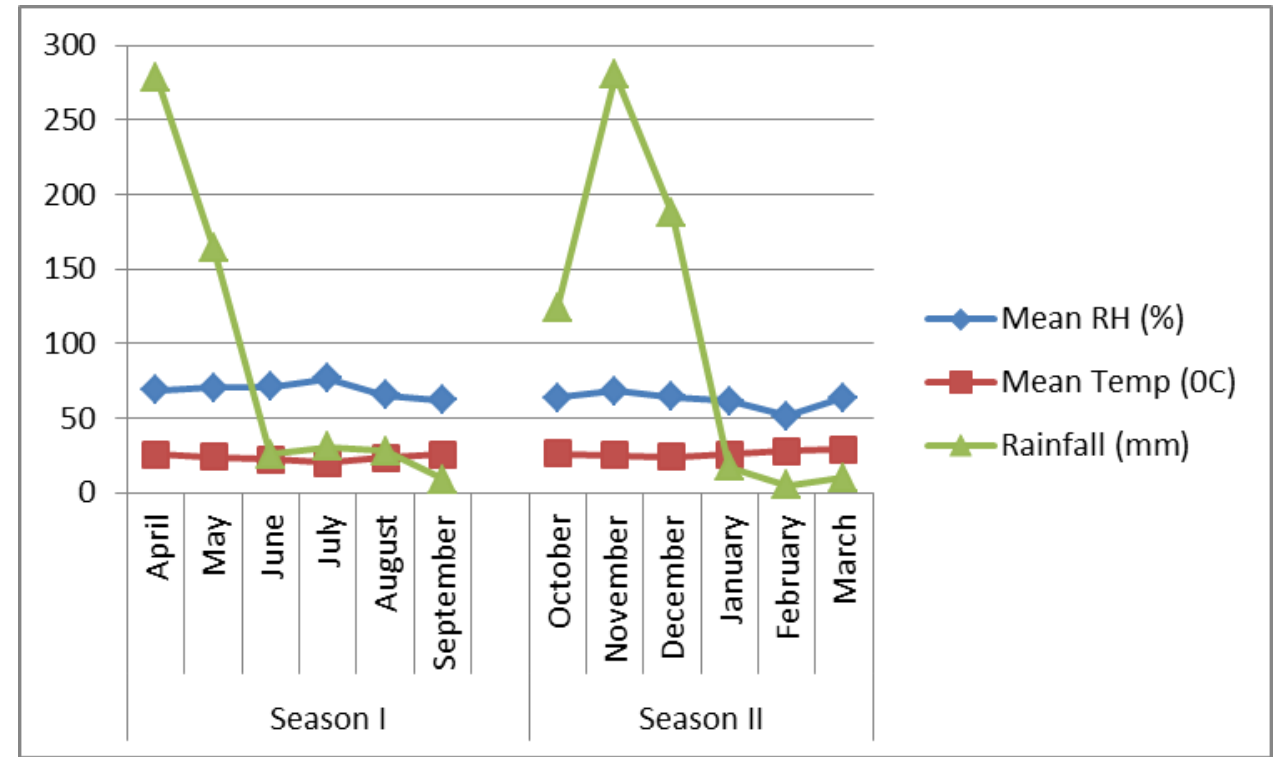

Fig 1 Variation of weather parameters in seasons I and II during growing of dryland hybrid maize in Embu county (2012-2013).

Table 2 Effect of irrigation and N-fertilizer on plant stand-count of dryland maize grown in Embu county in seasons I and II.

\begin{tabular}{lcccccccccc}
\hline \multirow{2}{*}{ Factor } & \multicolumn{4}{c}{ Season I (time in weeks after sowing) } & \multicolumn{5}{c}{ Season II (time in weeks after sowing) } \\
\cline { 2 - 11 } & 2 & 4 & 6 & 8 & 10 & 2 & 4 & 6 & 8 & 10 \\
\hline $\mathrm{I}_{1}$ & $50.7 \mathrm{c}^{*}$ & $45.2 \mathrm{c}$ & $43.8 \mathrm{~b}$ & $43.5 \mathrm{~b}$ & $43.5 \mathrm{~b}$ & $59.1 \mathrm{a}$ & $59.1 \mathrm{a}$ & $59.1 \mathrm{a}$ & $59.1 \mathrm{a}$ & $59.1 \mathrm{a}$ \\
$\mathrm{I}_{2}$ & $53.2 \mathrm{~b}$ & $48.3 \mathrm{ab}$ & $46.5 \mathrm{ab}$ & $45.8 \mathrm{ab}$ & $45.8 \mathrm{ab}$ & $60.1 \mathrm{a}$ & $59.9 \mathrm{a}$ & $59.8 \mathrm{a}$ & $59.8 \mathrm{a}$ & $59.8 \mathrm{a}$ \\
$\mathrm{I}_{3}$ & $53.9 \mathrm{ab}$ & $48.9 \mathrm{a}$ & $46.5 \mathrm{a}$ & $44.8 \mathrm{ab}$ & $44.8 \mathrm{ab}$ & $58.9 \mathrm{a}$ & $59.0 \mathrm{a}$ & $59.1 \mathrm{a}$ & $59.1 \mathrm{a}$ & $59.1 \mathrm{a}$ \\
$\mathrm{I}_{4}$ & $54.7 \mathrm{a}$ & $46.2 \mathrm{bc}$ & $44.4 \mathrm{ab}$ & $46.5 \mathrm{a}$ & $46.5 \mathrm{a}$ & $59.7 \mathrm{a}$ & $60.0 \mathrm{a}$ & $59.7 \mathrm{a}$ & $59.7 \mathrm{a}$ & $59.7 \mathrm{a}$ \\
Lsd & 1.484 & 2.478 & 2.730 & 2.576 & 2.576 & 3.167 & 3.322 & 3.243 & 3.243 & 3.243 \\
$\mathrm{~N}_{0}$ & $52.1 \mathrm{~b}$ & $48.3 \mathrm{a}$ & $42.6 \mathrm{~b}$ & $40.9 \mathrm{~b}$ & $40.9 \mathrm{~b}$ & $50.5 \mathrm{~b}$ & $51.1 \mathrm{~b}$ & $51.1 \mathrm{~b}$ & $51.1 \mathrm{~b}$ & $51.1 \mathrm{~b}$ \\
$\mathrm{~N}_{1}$ & $53.2 \mathrm{ab}$ & $45.2 \mathrm{~b}$ & $45.0 \mathrm{ab}$ & $46.5 \mathrm{a}$ & $46.5 \mathrm{a}$ & $62.4 \mathrm{a}$ & $62.3 \mathrm{a}$ & $61.8 \mathrm{a}$ & $61.8 \mathrm{a}$ & $61.8 \mathrm{a}$ \\
$\mathrm{N}_{2}$ & $53.0 \mathrm{ab}$ & $46.6 \mathrm{ab}$ & $46.2 \mathrm{a}$ & $45.2 \mathrm{a}$ & $45.2 \mathrm{a}$ & $60.7 \mathrm{a}$ & $60.3 \mathrm{a}$ & $60.9 \mathrm{a}$ & $60.9 \mathrm{a}$ & $60.9 \mathrm{a}$ \\
$\mathrm{N}_{3}$ & $54.4 \mathrm{a}$ & $48.4 \mathrm{a}$ & $46.8 \mathrm{a}$ & $47.3 \mathrm{a}$ & $47.3 \mathrm{a}$ & $62.9 \mathrm{a}$ & $62.7 \mathrm{a}$ & $62.1 \mathrm{a}$ & $62.1 \mathrm{a}$ & $62.1 \mathrm{a}$ \\
$\mathrm{N}_{4}$ & $52.9 \mathrm{ab}$ & $47.2 \mathrm{ab}$ & $45.9 \mathrm{a}$ & $45.8 \mathrm{a}$ & $45.8 \mathrm{a}$ & $60.8 \mathrm{a}$ & $61.1 \mathrm{a}$ & $60.1 \mathrm{a}$ & $60.1 \mathrm{a}$ & $60.1 \mathrm{a}$ \\
Lsd & 1.659 & 2.770 & 3.052 & 2.881 & 2.881 & 3.541 & 3.713 & 3.626 & 3.626 & 3.626 \\
$\mathrm{R}^{2}$ & 0.841 & 0.741 & 0.733 & 0.744 & 0.744 & 0.6173 & 0.7245 & 0.7018 & 0.7018 & 0.7018 \\
$\mathrm{R}-\mathrm{MSE}$ & 1.995 & 3.334 & 3.370 & 3.464 & 3.464 & 1.648 & 4.4665 & 4.360 & 4.360 & 4.360 \\
Cov & 3.756 & 7.066 & 8.100 & 7.672 & 7.672 & 9.747 & 7.5068 & 7.341 & 7.341 & 7.341 \\
$\mathrm{I} \times \mathrm{N}$ & 0.3523 & 0.6104 & 0.4236 & 0.8444 & 0.8444 & 0.8211 & 0.9451 & 0.9896 & 0.9896 & 0.9896 \\
Mean & 53.1 & 47.2 & 45.3 & 45.1 & 45.1 & 59.4 & 59.5 & 59.4 & 59.40 & 59.40 \\
\hline
\end{tabular}

* Means under different treatments (irrigation and $\mathrm{N}$-fertilizer) in same column followed by the same letters are not significantly different.

that the experiment was quite objective and its findings reliable at $\mathrm{P}<0.05$ confidence level.

\subsection{Effect of Irrigation on Plant Height}

Plant height of dryland hybrid maize was observed to increase under both treatments of irrigation regimes and nitrogen fertilizer applications in season I (Table $3)$. There were significant differences in height of the maize under all irrigation application levels. But under $\mathrm{N}$-fertilizer treatments, significant differences in plant 
Rates in Embu County, Kenya

height were recorded at all times of observation. In all cases, treatments without fertilizer application $\left(\mathrm{N}_{0}\right)$ resulted in the shortest plants. The plant height was statistically taller at six and eight weeks after sowing with under nitrogen treatments of $75 \mathrm{~kg} / \mathrm{ha}$ and 90 $\mathrm{kg} / \mathrm{ha}$ (Table 3). This implies that at time of active vegetative and productive growth of dryland maize, plant height was determined by N-rates and increased with higher fertilizer applications.

The findings revealed that plant height increased with time of growth under both irrigation applications and nitrogen fertilizer treatments, varying between 9.1 cm at 2 WAS to $213.4 \mathrm{~cm}$ at 16 WAS (Table 3).

In Season II, plant height increased up to 14 weeks after sowing (WAS) after which it remained constant, varying from $16.9 \mathrm{~cm}$ to $237.7 \mathrm{~cm}$ under both irrigation application and $\mathrm{N}$-fertilizer rates (Table 4). It was noted in this season that plant height at all phases of growth decreased with increased irrigation applications, being statistically similar up to 10 WAS,

Table 3 Effect of irrigation and N-fertilizer on plant height $(\mathrm{cm})$ of maize in season $\mathrm{I}$.

\begin{tabular}{lllllllll}
\hline \multirow{2}{*}{ Factor } & \multicolumn{7}{c}{ Time in weeks after sowing (WAS) } \\
\cline { 2 - 9 } & 2 & 4 & 6 & 8 & 10 & 12 & 14 & 16 \\
\hline $\mathrm{I}_{1}$ & $8.9 \mathrm{a}$ & $27.2 \mathrm{a}$ & $58.5 \mathrm{a}$ & $106.5 \mathrm{a}$ & $159.9 \mathrm{a}$ & $204.0 \mathrm{a}$ & $213.1 \mathrm{a}$ & $215.5 \mathrm{a}$ \\
$\mathrm{I}_{2}$ & $8.9 \mathrm{a}$ & $27.5 \mathrm{a}$ & $61.2 \mathrm{a}$ & $107.8 \mathrm{a}$ & $162.1 \mathrm{a}$ & $205.2 \mathrm{a}$ & $212.1 \mathrm{a}$ & $214.4 \mathrm{a}$ \\
$\mathrm{I}_{3}$ & $9.1 \mathrm{a}$ & $28.4 \mathrm{a}$ & $62.0 \mathrm{a}$ & $111.4 \mathrm{a}$ & $163.4 \mathrm{a}$ & $206.9 \mathrm{a}$ & $214.4 \mathrm{a}$ & $217.9 \mathrm{a}$ \\
$\mathrm{I}_{4}$ & $9.5 \mathrm{a}$ & $29.8 \mathrm{a}$ & $61.1 \mathrm{a}$ & $112.4 \mathrm{a}$ & $164.5 \mathrm{a}$ & $204.7 \mathrm{a}$ & $213.7 \mathrm{a}$ & $215.7 \mathrm{a}$ \\
$\mathrm{LSD}$ & $\mathrm{NS}$ & $\mathrm{NS}$ & $\mathrm{NS}$ & $\mathrm{NS}$ & $\mathrm{NS}$ & $\mathrm{NS}$ & $\mathrm{NS}$ & 9.425 \\
$\mathrm{~N}_{0}$ & $8.5 \mathrm{~b}$ & $22.3 \mathrm{~b}$ & $39.6 \mathrm{c}$ & $72.9 \mathrm{~d}$ & $113.6 \mathrm{c}$ & $166.6 \mathrm{c}$ & $186.9 \mathrm{~b}$ & $191.3 \mathrm{c}$ \\
$\mathrm{N}_{1}$ & $9.6 \mathrm{a}$ & $30.5 \mathrm{a}$ & $62.6 \mathrm{~b}$ & $111.8 \mathrm{c}$ & $161.3 \mathrm{~b}$ & $207.0 \mathrm{~b}$ & $210.7 \mathrm{a}$ & $212.5 \mathrm{~b}$ \\
$\mathrm{~N}_{2}$ & $9.1 \mathrm{ab}$ & $29.9 \mathrm{a}$ & $63.9 \mathrm{~b}$ & $115.4 \mathrm{bc}$ & $166.1 \mathrm{~b}$ & $216.8 \mathrm{a}$ & $223.5 \mathrm{a}$ & $225.4 \mathrm{~b}$ \\
$\mathrm{~N}_{3}$ & $8.8 \mathrm{ab}$ & $29.2 \mathrm{a}$ & $64.8 \mathrm{~b}$ & $121.5 \mathrm{ab}$ & $181.6 \mathrm{a}$ & $218.4 \mathrm{a}$ & $221.6 \mathrm{a}$ & $222.6 \mathrm{ab}$ \\
$\mathrm{N}_{4}$ & $9.2 \mathrm{ab}$ & $29.4 \mathrm{a}$ & $72.5 \mathrm{a}$ & $126.0 \mathrm{a}$ & $187.4 \mathrm{a}$ & $217.0 \mathrm{a}$ & $224.0 \mathrm{a}$ & $227.4 \mathrm{a}$ \\
$\mathrm{LSD}$ & 0.875 & 3.800 & 5.539 & 6.837 & 9.413 & 9.778 & 14.621 & 10.538 \\
Mean & 9.1 & 28.2 & 60.7 & 109.5 & 162.0 & 205.2 & 213.3 & 215.9 \\
\hline
\end{tabular}

* Means with the same letter are not significantly different.

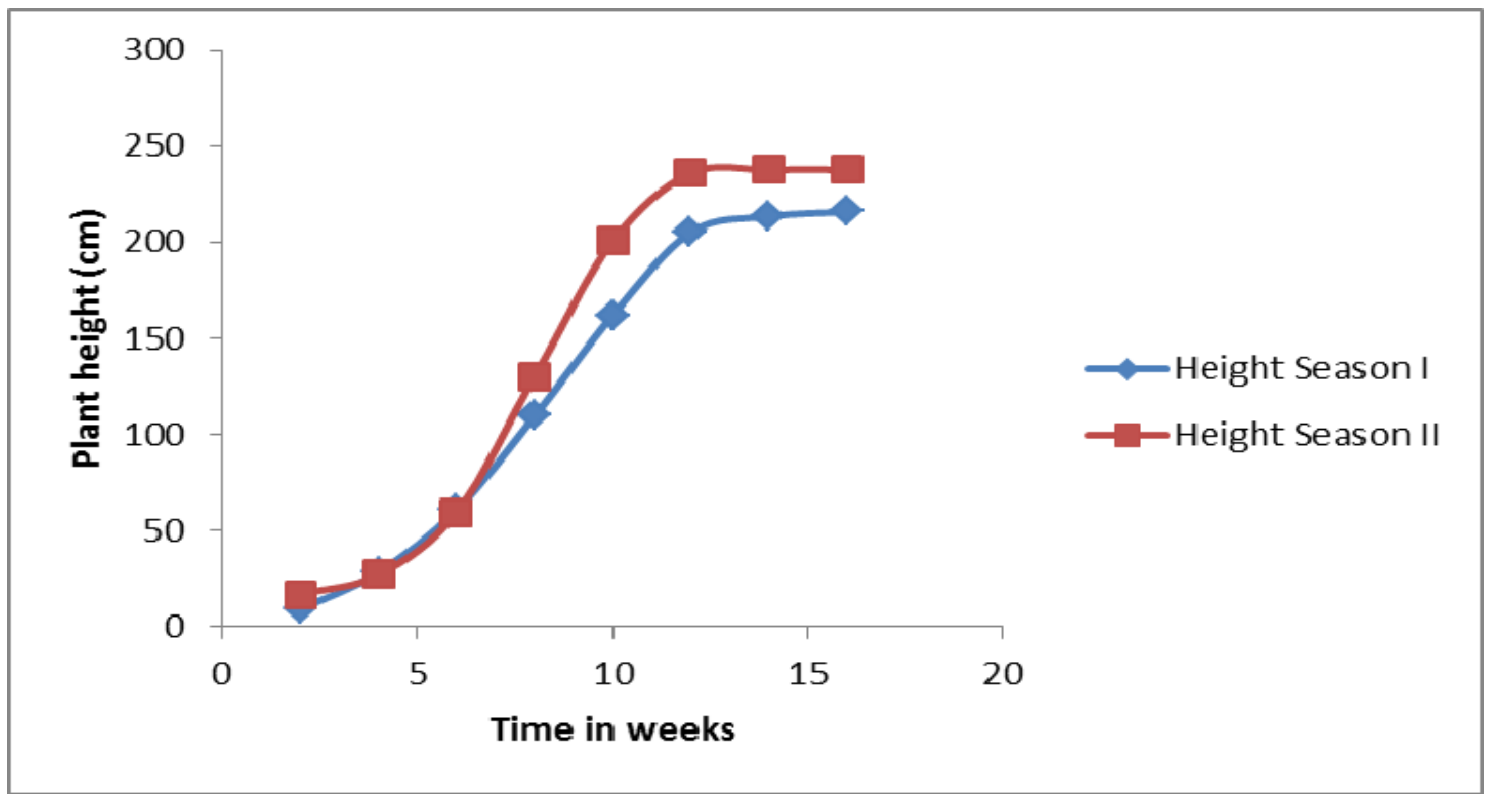

Fig. 3 Mean plant height over time of growth in season I and season II. 
after which the plants with more irrigation remained consistently shorter till maximum height was attained. This was not observed in season I where the reverse seemed to be the case and maximum plant height was attained earlier. This may be due to the relatively higher rainfall amounts received and the prevailing ambient temperatures in season II compared to season I which was characterized with lower temperatures in the latter period of plant growth (Table 1). Natural precipitation appears to influence the growth patterns of the maize crop in these two seasons.

\subsection{Effect of Irrigation and Nitrogen Fertilizer on Plant Growth Rate}

Under nitrogen fertilizer treatments in season II, plant height of the dryland hybrid maize increased with time of growth till maximum height was attained at $12 \mathrm{WAS}$, varying from $16.9 \mathrm{~cm}$ at 2 WAS to 237.7 $\mathrm{cm}$ at 12 WAS (Table 4). Plant height was significantly different with plants that had no $\mathrm{N}$-fertilizer consistently resulting in shorter plants compared with the fertilized treatments throughout the period of observation. The plant height generally increased with increase in $\mathrm{N}$-fertilizer rates. At 2 WAS, only treatments without $\mathrm{N}$-fertilizer had shorter plants compared to the other $\mathrm{N}$-fertilizer treatments. In the subsequent growth phases, the plant heights of $\mathrm{N}_{1}$, $\mathrm{N}_{2}$ and $\mathrm{N}_{3}$ treatments were not significantly different from each other and plants of $\mathrm{N}_{4}$ treatments remained taller compared with plants from other $\mathrm{N}$-fertilizer treatments. The values of $\mathrm{R}^{2}$ varied from $58.5 \%$ at 4 WAS to $80.4 \%$ at 12 WAS, reflecting a general increase in model reliability over time of growth. This shows the experimental design was able to explain plant height variations significantly for the dryland hybrid maize.

\subsection{Effect of Irrigation and N-fertilizer on Number of Leaves Per Plant}

The findings showed that the number of leaves per plant increased from 4.1 to 14.0 at 2 weeks and 12 weeks after sowing (WAS) in season I and 5.7 to 15.4 in season II over the period of observation (Table 5). The number of leaves per plant stabilized at between

Table 4 Effect of irrigation and N-fertilizer on plant height $(\mathrm{cm})$ of maize in season II.

\begin{tabular}{|c|c|c|c|c|c|c|c|c|}
\hline \multirow{2}{*}{ Factor } & \multicolumn{8}{|c|}{ Time in weeks after sowing (WAS) } \\
\hline & 2 & 4 & 6 & 8 & 10 & 12 & 14 & 16 \\
\hline $\mathrm{I}_{1}$ & $17.4 \mathrm{a}$ & $28.6 \mathrm{a}$ & $66.2 \mathrm{a}$ & $128.9 \mathrm{a}$ & $209.0 \mathrm{a}$ & $243.5 \mathrm{a}$ & $243.5 \mathrm{a}$ & $243.5 \mathrm{a}$ \\
\hline $\mathrm{I}_{2}$ & $17.3 \mathrm{a}$ & $28.0 \mathrm{ab}$ & $61.7 \mathrm{ab}$ & $132.7 \mathrm{a}$ & $208.0 \mathrm{a}$ & $235.8 \mathrm{ab}$ & $236.0 \mathrm{ab}$ & $236.0 \mathrm{ab}$ \\
\hline $\mathrm{I}_{3}$ & $16.5 \mathrm{a}$ & $26.0 \mathrm{ab}$ & $54.8 \mathrm{~b}$ & $120.9 \mathrm{a}$ & $195.6 \mathrm{ab}$ & $232.8 \mathrm{ab}$ & $239.3 \mathrm{ab}$ & $239.3 \mathrm{ab}$ \\
\hline $\mathrm{I}_{4}$ & $16.4 \mathrm{a}$ & $25.0 \mathrm{~b}$ & $54.8 \mathrm{~b}$ & $138.4 \mathrm{a}$ & $189.4 b$ & $231.7 \mathrm{~b}$ & $232.3 b$ & $232.3 b$ \\
\hline Lsd & 1.226 & 3.395 & 9.23 & 25.71 & 17.66 & 11.13 & 9.30 & 9.30 \\
\hline $\mathrm{N}_{0}$ & $15.3 b$ & $22.4 \mathrm{c}$ & $41.4 \mathrm{c}$ & $99.4 \mathrm{c}$ & $164.4 \mathrm{c}$ & $207.3 \mathrm{c}$ & $212.6 \mathrm{c}$ & $212.6 \mathrm{c}$ \\
\hline $\mathrm{N}_{1}$ & $17.7 \mathrm{a}$ & $29.4 \mathrm{ab}$ & $60.9 b$ & $123.7 \mathrm{bc}$ & $199.8 b$ & $231.2 \mathrm{~b}$ & $233.7 b$ & $233.7 b$ \\
\hline $\mathrm{N}_{2}$ & $17.0 \mathrm{a}$ & $26.4 \mathrm{ab}$ & $61.8 \mathrm{~b}$ & $134.6 \mathrm{ab}$ & 207.9ab & $242.7 \mathrm{ab}$ & $242.6 \mathrm{ab}$ & $242.6 \mathrm{ab}$ \\
\hline $\mathrm{N}_{3}$ & $16.9 a$ & $26.2 \mathrm{bc}$ & $59.7 b$ & $153.0 \mathrm{a}$ & $220.1 \mathrm{a}$ & $247.0 \mathrm{a}$ & $249.1 \mathrm{a}$ & 249.1a \\
\hline $\mathrm{N}_{4}$ & $17.8 \mathrm{a}$ & $30.1 \mathrm{a}$ & $73.1 \mathrm{a}$ & $140.4 \mathrm{ab}$ & $210.7 \mathrm{ab}$ & $251.6 \mathrm{a}$ & $250.4 \mathrm{a}$ & $250.4 \mathrm{a}$ \\
\hline Lsd & 1.37 & 3.80 & 10.32 & 28.74 & 19.75 & 12.45 & 10.39 & 10.39 \\
\hline $\mathrm{R}^{2}$ & 0.6173 & 0.5848 & 0.6921 & 0.5921 & 0.7101 & 0.7518 & 0.8040 & 0.8040 \\
\hline R-MSE & 9.749 & 16.969 & 20.900 & 26.539 & 11.842 & 6.344 & 5.259 & 5.259 \\
\hline $\mathrm{CoV}$ & 1.648 & 4.564 & 12.500 & 34.561 & 23.750 & 14.970 & 12.500 & 12.500 \\
\hline $\mathrm{I} \times \mathrm{N}$ & 0.6133 & 0.9461 & 0.4267 & 0.4344 & 0.8160 & 0.6430 & 0.3642 & 0.3642 \\
\hline Mean & 16.9 & 26.9 & 59.4 & 130.2 & 200.6 & 235.9 & 237.7 & 237.7 \\
\hline
\end{tabular}

\footnotetext{
* Means of irrigation application and nitrogen fertilizer treatments with the same letter are not significantly different.
} 


\section{Rates in Embu County, Kenya}

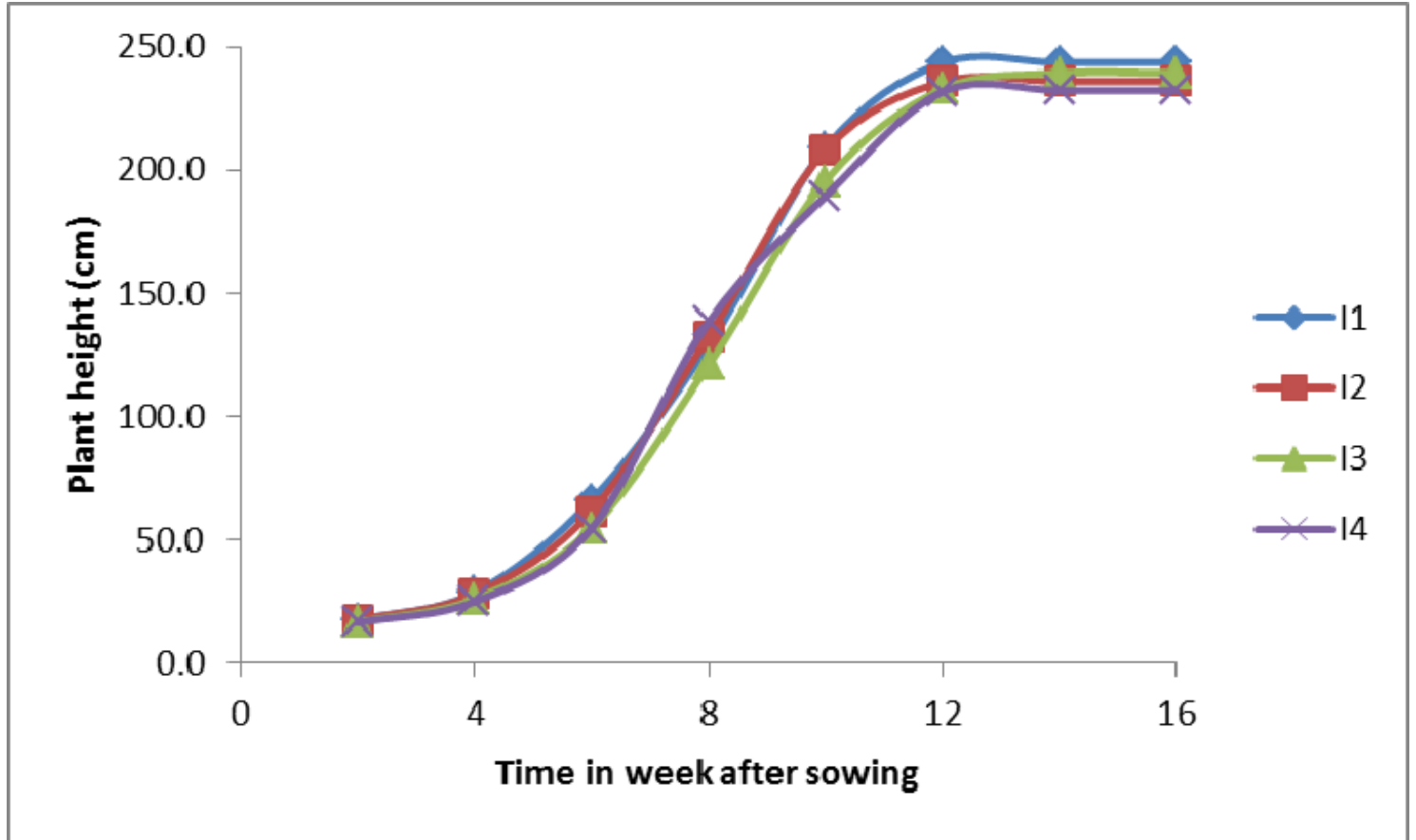

(a)

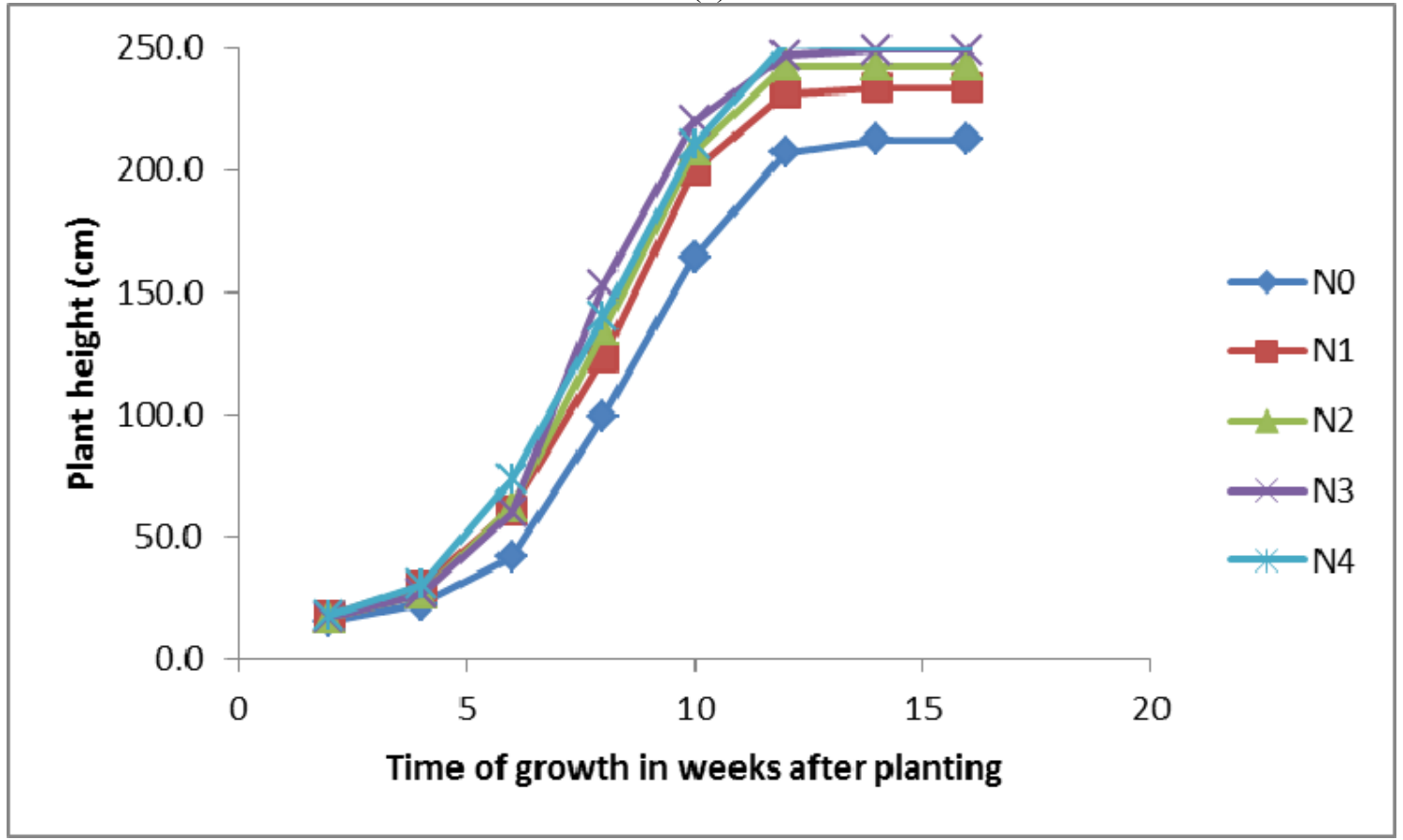

(b)

Fig. 4 Variation of plant height of DK8031 maize variety over time of growth under (a) irrigation and (b) nitrogen fertilizer rates in season $I$.

10 WAS and 12 WAS. At all times of recording except by 6 WAS, irrigation applications did not result in significantly different number of leaves per plant. By the sixth week after sowing, the maize crop with only the starter irrigation had significantly lower leaves per plant compared to the other irrigation treatments. At the time of greatest growth rate the crop was disadvantaged due limited soil moisture.

Nitrogen fertilizer application had significant effects on the number of leaves per plant at all times 
of plant growth except at 2 WAS (Table 5). This would be expected since the seedlings are mainly dependent on the seed reserves for growth at this early growth phase. The $\mathrm{N}_{0}$ treatments resulted in significantly fewer leaves per plant and $\mathrm{N}_{4}$ treatments gave the most number of leaves per plant compared treatments (Table 5). The number of leaves per plant from the other $\mathrm{N}$-fertilizer treatments was statistically similar throughout the period of observation.

In season II, the number of leaves per plant of the dryland hybrid maize was statistically except for the early period of growth up to 4 WAS (Table 5). This would be because the seedlings are using food reserves for germination, emergence and early crop establishment. It appears also that the fertilizer application retarded early leave growth, thus, non-fertilized crop had relatively more leaves per plant than the fertilized ones. As the maize matured over time, the need for external nutrition enables the fertilized crops to develop more leaves till all treatments reach the potential or genetic maximum of about 14 leaves per plant by the 10th WAS (Table 5).
Plants in season II had more leaves per plant compared to those of season $\mathrm{I}$ at all times of observation (Fig. 1).

\section{Discussions}

Research has revealed that irrigation deficit causes a reduction in plant height, accelerates leave senescence and lowers LAI [15]. Plant height and number of leaves per plant of spring planted irrigated maize is reported to increase with increasing rates of nitrogen in semi-arid environments [16]. A research carried out to evaluate the effects of plant population density on in Sri Lanka and Nigeria under supplementary irrigation revealed plant heights of hybrid maize vary between $229 \mathrm{~cm}$ and $250 \mathrm{~cm}$ [16, 17]. A higher number of 12.7 leaves per plant of maize under stress and non-stress environments have been reported [18]. These results were comparable the one in this study and collaborates well with the findings of other researcher who found out that nitrogen rich poultry manure significantly improves vegetative growth [19].

Table 5 Number of leaves per plant of DK8031 maize variety in seasons I and II grown in Embu, Kenya.

\begin{tabular}{|c|c|c|c|c|c|c|c|c|c|c|c|c|}
\hline \multirow{2}{*}{ Factor } & \multicolumn{6}{|c|}{ Season I (weeks after sowing) } & \multicolumn{6}{|c|}{ Season II (weeks after sowing) } \\
\hline & 2 & 4 & 6 & 8 & 10 & 12 & 2 & 4 & 6 & 8 & 10 & 12 \\
\hline $\mathrm{I}_{1}$ & $4.1 \mathrm{a}$ & $6.6 \mathrm{a}$ & $9.4 \mathrm{~b}$ & $11.9 \mathrm{a}$ & $13.9 \mathrm{a}$ & $13.9 \mathrm{a}$ & $5.9 \mathrm{a}$ & $7.8 \mathrm{a}$ & $13.5 \mathrm{a}$ & $14.9 \mathrm{a}$ & $15.4 \mathrm{a}$ & $15.4 \mathrm{a}$ \\
\hline $\mathrm{I}_{2}$ & $4.0 \mathrm{a}$ & $6.8 \mathrm{a}$ & $9.6 \mathrm{ab}$ & $11.6 \mathrm{a}$ & $13.9 \mathrm{a}$ & $13.9 \mathrm{a}$ & $5.8 \mathrm{ab}$ & $7.9 \mathrm{a}$ & $13.8 \mathrm{a}$ & $14.5 \mathrm{a}$ & $15.4 \mathrm{a}$ & $15.4 \mathrm{a}$ \\
\hline $\mathrm{I}_{3}$ & $4.1 \mathrm{a}$ & $6.9 \mathrm{a}$ & $10.1 \mathrm{a}$ & $11.8 \mathrm{a}$ & $13.9 \mathrm{a}$ & $14.1 \mathrm{a}$ & $5.6 \mathrm{~b}$ & $7.5 b$ & $13.5 \mathrm{a}$ & $14.6 \mathrm{a}$ & $15.4 \mathrm{a}$ & $15.4 \mathrm{a}$ \\
\hline $\mathrm{I}_{4}$ & $4.1 \mathrm{a}$ & $6.9 \mathrm{a}$ & $10.0 \mathrm{ab}$ & $12.0 \mathrm{a}$ & $14.2 \mathrm{a}$ & $14.3 \mathrm{a}$ & $5.6 \mathrm{~b}$ & $7.5 b$ & $13.7 \mathrm{a}$ & $14.4 \mathrm{a}$ & $15.3 \mathrm{a}$ & $15.3 \mathrm{a}$ \\
\hline Lsd & 0.187 & 0.3029 & 0.3927 & 0.4698 & 0.5111 & 0.4688 & 0.2835 & 0.3593 & 0.4479 & 0.5161 & 0.5578 & 0.5578 \\
\hline $\mathrm{N}_{0}$ & $4.0 \mathrm{a}$ & $6.4 \mathrm{c}$ & $8.4 \mathrm{c}$ & $10.4 \mathrm{c}$ & $12.2 \mathrm{c}$ & $12.6 \mathrm{c}$ & $5.4 \mathrm{~b}$ & $6.8 \mathrm{c}$ & $12.3 \mathrm{~d}$ & $13.4 \mathrm{~b}$ & $14.3 b$ & $14.3 \mathrm{~b}$ \\
\hline $\mathrm{N}_{1}$ & $4.1 \mathrm{a}$ & $6.9 \mathrm{ab}$ & $9.9 \mathrm{~b}$ & $12.1 \mathrm{ab}$ & $14.2 \mathrm{~b}$ & $14.2 \mathrm{~b}$ & $5.9 \mathrm{a}$ & 7.9ab & $13.3 \mathrm{c}$ & $14.7 \mathrm{a}$ & $15.4 \mathrm{a}$ & $15.4 \mathrm{a}$ \\
\hline $\mathrm{N}_{2}$ & $4.1 \mathrm{a}$ & $6.6 \mathrm{bc}$ & $10.0 \mathrm{~b}$ & $11.8 \mathrm{~b}$ & $14.1 \mathrm{~b}$ & $14.1 \mathrm{~b}$ & $5.8 \mathrm{a}$ & $7.7 \mathrm{~b}$ & $13.8 \mathrm{~b}$ & $14.8 \mathrm{a}$ & $15.5 \mathrm{a}$ & $15.5 \mathrm{a}$ \\
\hline $\mathrm{N}_{3}$ & $4.1 \mathrm{a}$ & $6.9 \mathrm{ab}$ & $10.2 \mathrm{ab}$ & $12.4 \mathrm{a}$ & $14.4 \mathrm{ab}$ & $14.4 \mathrm{ab}$ & $5.6 a b$ & $7.8 \mathrm{ab}$ & $14.2 \mathrm{ab}$ & $14.8 \mathrm{a}$ & $15.9 \mathrm{a}$ & $15.9 \mathrm{a}$ \\
\hline $\mathrm{N}_{4}$ & $4.1 \mathrm{a}$ & $7.1 \mathrm{a}$ & $10.5 \mathrm{a}$ & $12.5 \mathrm{a}$ & $14.9 \mathrm{a}$ & $14.9 \mathrm{a}$ & $5.8 \mathrm{a}$ & $8.1 \mathrm{a}$ & $14.5 \mathrm{a}$ & $15.3 \mathrm{a}$ & $15.9 \mathrm{a}$ & $15.9 \mathrm{a}$ \\
\hline Lsd & 0.2092 & 0.3387 & 0.4391 & 0.5252 & 0.5714 & 0.5241 & 0.3170 & 0.4017 & 0.5007 & 0.5770 & 0.6337 & 0.6237 \\
\hline $\mathrm{R}^{2}$ & 0.4534 & 0.5923 & 0.8348 & 0.7724 & 0.7997 & 0.7718 & 0.5763 & 0.7224 & 0.7866 & 0.6877 & 0.6128 & 0.6128 \\
\hline R-MSE & 0.2520 & 0.4028 & 0.5280 & 0.6316 & 0.6872 & 0.6303 & 0.3812 & 0.4830 & 0.6021 & 0.6938 & 0.7500 & 0.7500 \\
\hline $\mathrm{CoV}$ & 6.186 & 6.0218 & 5.3768 & 5.3400 & 4.9230 & 4.4886 & 6.6648 & 6.2828 & 4.4216 & 4.7480 & 4.8706 & 4.8706 \\
\hline $\mathrm{I} \times \mathrm{N}$ & 0.7102 & 0.4284 & 0.2930 & 0.5195 & 0.6391 & 0.8201 & 0.7092 & 0.6270 & 0.9497 & 0.6063 & 0.4945 & 0.4945 \\
\hline Mean & 4.1 & 6.8 & 9.8 & 11.8 & 14.0 & 14.0 & 5.7 & 7.9 & 13.6 & 14.6 & 15.4 & 15.4 \\
\hline
\end{tabular}

* Means under respective treatments in a column with the same letter are not significantly different. 


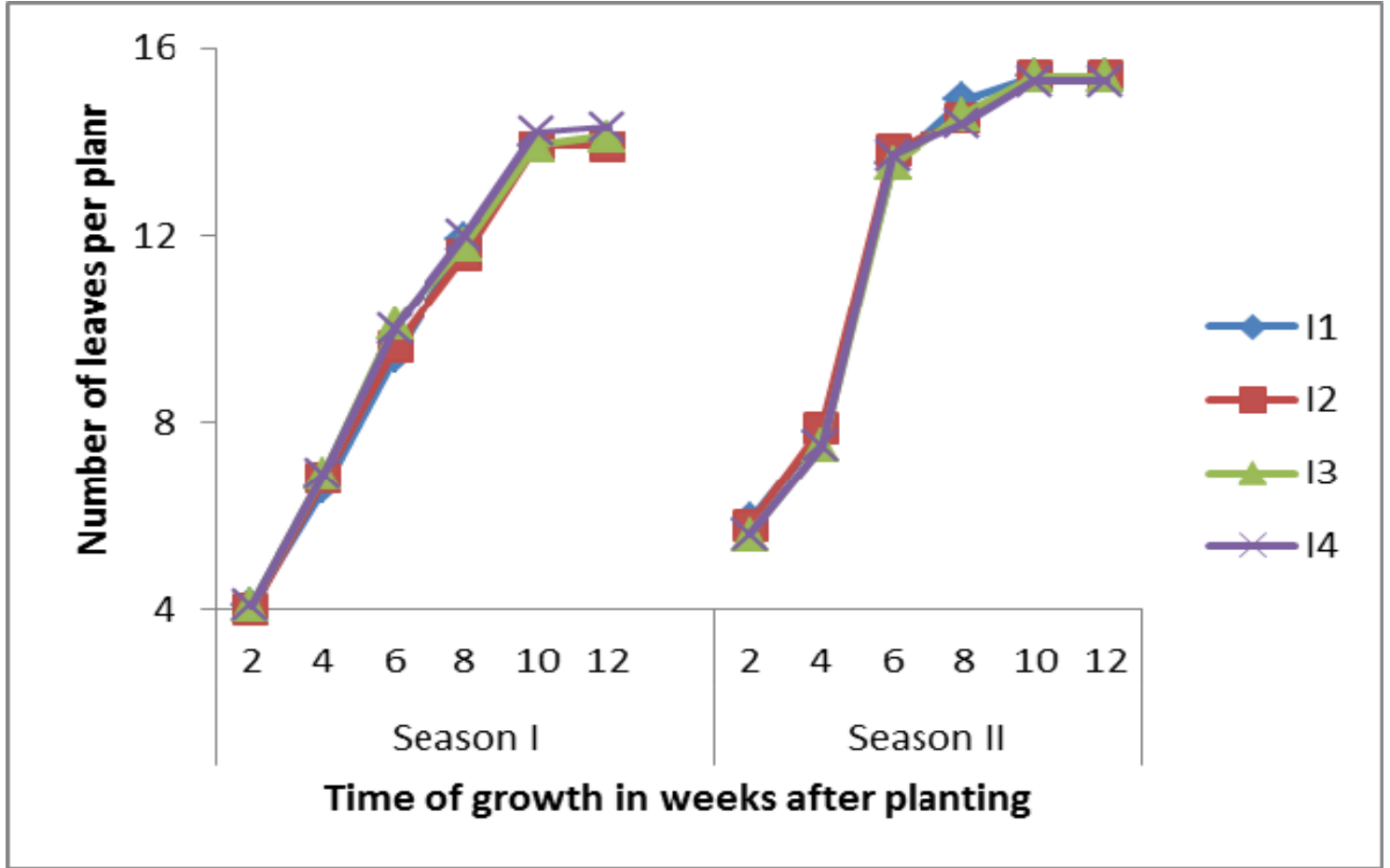

Fig. 5 Effect of irrigation application (I) on the number of leaves per plant of DK8031 maize variety in season I and season II.

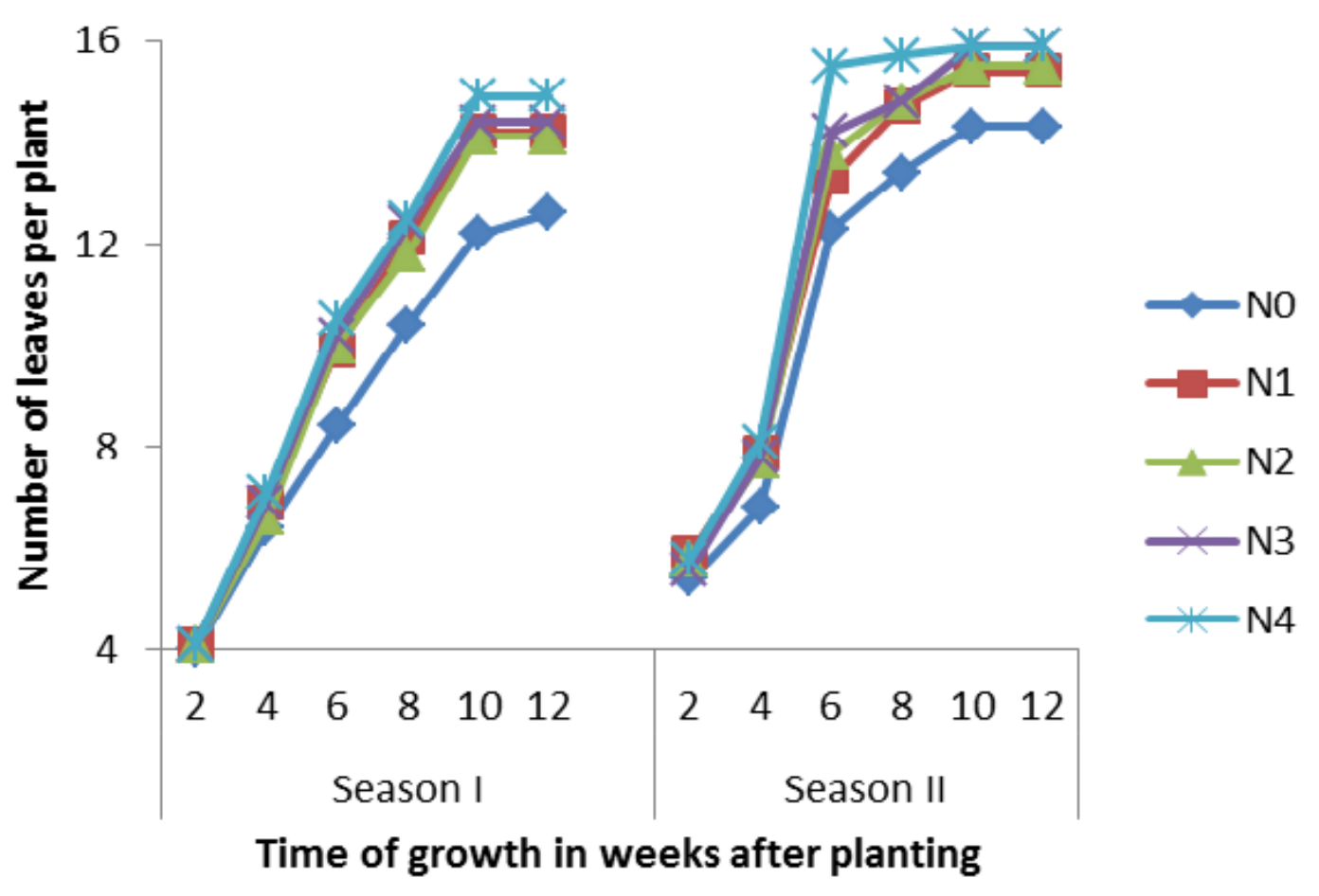

Fig. 6 Effect of nitrogen fertilizer rates (N) on the number of leaves per plant of DK8031 maize variety in season I and season II. 


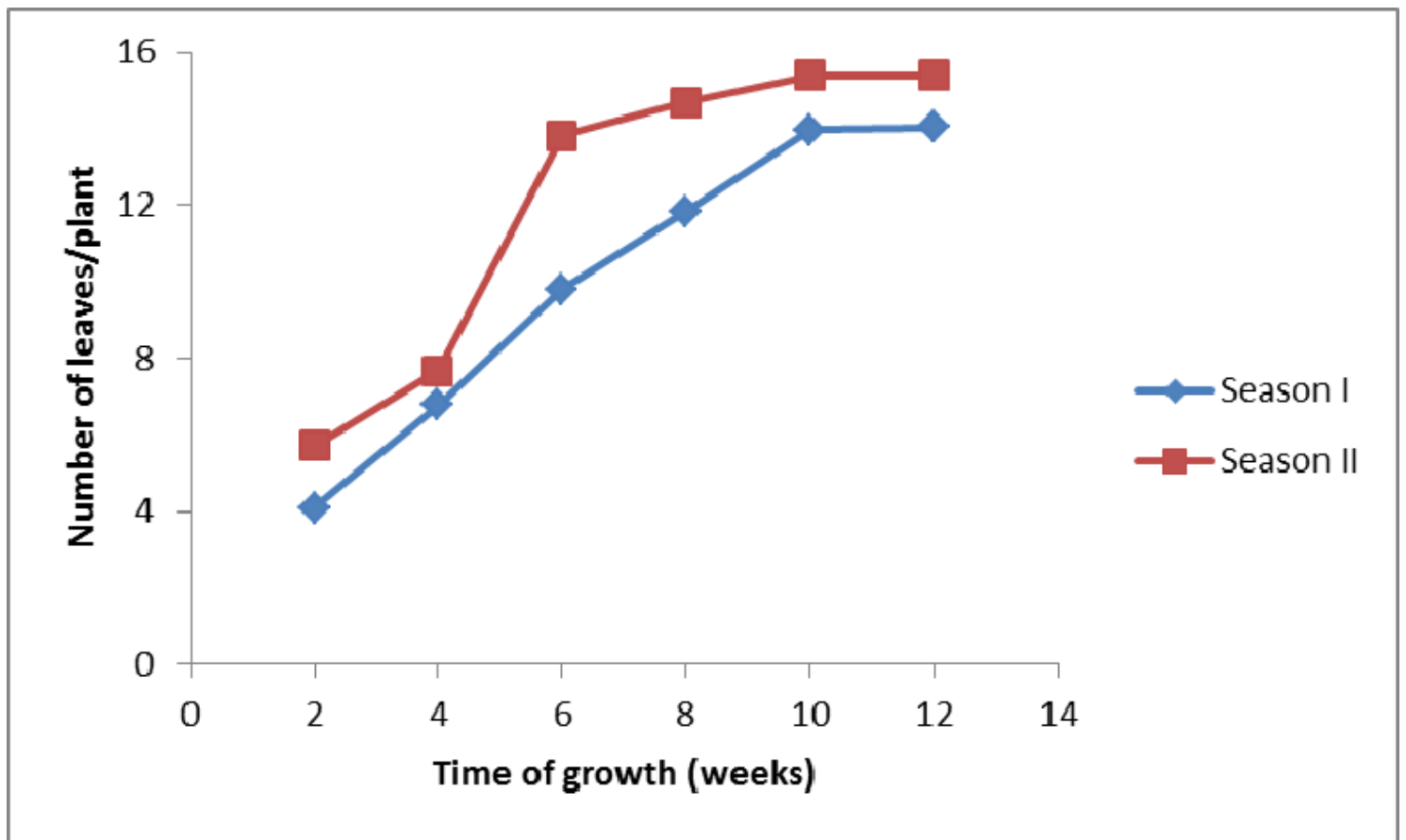

Fig. 7 Number of leaves per plant of dryland hybrid maize in season I and season II

Working on combinations of organic and inorganic fertilizers, it was shown that the plant height of maize at 8 weeks after sowing was highest with inorganic fertilizer application [20]. Work has indicated a linear response of plant height to nitrogen fertilizer increase that peaked at $100 \mathrm{~kg} \mathrm{~N} / \mathrm{ha}$, underscoring the importance of nitrogen in growth and development of maize crop [21, 22]. In Nigeria, experiments showed that use of nitrogen promoted plant height, number of leaves per plant among other growth parameters [23]. In west Africa, vegetative growth has been observed to be improved greatly by use of poultry manure which is known to contain high levels of nitrogen nutrient, with plant height and number of leaves per plant varying between $152 \mathrm{~cm}$ to $168 \mathrm{~cm}$ and 3.1-7.4 leaves per plant [19]. In Sudan, different nitrogen sources revealed increased plant height and number of leaves per plant in fertilizer treatments with higher levels of nitrogen fertilizer, with heights and leaves in excess of $152 \mathrm{~cm}$ and 16 leaves per plant [24].

In the current study, the plant height and number of leaves per plant peaked at three irrigation applications and $105 \mathrm{~kg} \mathrm{~N} / \mathrm{ha}$. This showed that in rain deficient environments where maize is grown, irrigation and nitrogen fertilizer use can greatly improve plant growth. This is important because leaves are the centers of carbon fixation through photosynthesis while taller plants ensure optimum capture of photosynthetically active radiation. In effect, the grain and biological yields of the crop will be increased in the long run. The nitrogen fertilizer effect on the growth parameters appeared to be more significant because the nutrient directly contributes to growth while water availability complements its utilization and ensures survival of the crop, hence, the stand counts noted. The stand count tended to decrease over growing period in both season due to death of plants that would not survive the environmental conditions under both irrigation and nitrogen fertilizer treatments. The sufficient available moisture in season II resulted in higher stand count that remained relatively unchanged throughout the growing period of the maize crop and contributed to the taller plants recorded.

\section{Conclusions}

It was concluded that use of three supplementary irrigations with rates of nitrogen fertilizer rates of 


\section{Rates in Embu County, Kenya}

90-100 kg/ha promotes the growth of DK8031 maize variety when grown in Embu County, Kenya. These are optimal rates under the circumstances which will in effect imply increased grain and biological yield of the crop. With sufficient total precipitation stand count remains relatively the same among irrigation and nitrogen fertilizer treatments. However, nitrogen fertilizer rates had a more profound effect on the growth parameters compared to the irrigation applications.

\section{References}

[1] Bationo, A., Waswa, B., Kihara, J., and Kimetu, J. 2007. "Advances in Integrated Soil Fertility Management in Sub-Saharan Africa: Challenges and Opportunities." Accessed September 7, 2011. http://www.springer.com/life+sciences/agriculture/book/9 78-1-4020-5759-5.

[2] Ketiem, P. K., Kipkorir, E. C., and Omondi, P. 2008. "Modeling Effects of Climate Change on Maize Production in Kenya: A Case Study of Two Agro-Climatic Zones." In Proceedings of the 11th KARI Biennial Scientific Conference, 10-14.

[3] Widtose, J. A. 2010. Irrigation Practices. Jodhpur: AGROBIOS, Agro House.

[4] Ragassa, E. N., Munir, A. H., Gina, E. C., Helle, M. R., Lawrence, S., and Barbar, K. 2010. "Agricultural Water Management and Poverty Linkages." Agricultural Water Management 97: 520-527.

[5] Hanjra, M. A., Ferede, T., and Gutta, D. G., 2009. "Reducing Poverty in Sub-Saharan Africa through Investments in Water and Other Priorities." Agricultural Water Management 96 (7): 1062-1070.

[6] Munir, Hajrat, A., Tandele, Ferede, and Debel, Gemachu, Gutta. 2009. "Reducing Poverty in Sub-Saharan Africa through Investments in Water and Other Priorities." Agricultural Water Management 96: 1062-1070.

[7] United Nations (UN). 2000. "Millennium Declaration Adopted by the Millennium Summit of World Leaders at the General.” In UN Millennium Declaration, 55.

[8] Hayano-Kanashiro, C., Calderon-Vazquez, C., Ibarra-Laclette, E., Herrera-Estrella, L., and Simpson, J. 2009. "Analysis of Gene Expression and Physiological Responses in Three Mexican Maize Landraces under Drought Stress and Recovery Irrigation.” PLOS ONE 4 (10): e7531. doi:10.1371/journal.pone.0007531.

[9] Madison, D., 2006. "The Centre for Environmental Economics and Policy in Africa, CEEPA, 2006.” Special
Series on Climate Change and Agriculture in Africa 10: 8-47.

[10] Sharma, R. K., and Sharma, T. K. 2002. Irrigation Engineering (Including Hydrology). New Delhi: S. Chand and Company Ltd..

[11] Michael, A. M. 1983. Irrigation: Theory and Practice. New Delhi: Vikas Publishing House Pvt Ltd..

[12] Mugendi, D. N., Mucher-Muna, M. M., and Mugwe, J. N. 2006. Soil Fertility: Enhancing Community Extension. Nairobi, Kenya: Manilla Publishers.

[13] Food and Agriculture Organization, FAO. 1989. "Environment and Agriculture: Environmental Problems Affecting Agriculture in the Asia and Pacific Region." In World Food Day Symposium, 51-60.

[14] Jaetzold, R., and Schmidt, H. 1983. Natural Conditions and Farm Management Information, Part C: East Kenya (Eastern and Coast Provinces). Kenya: Ministry of Agriculture Farm Management.

[15] Bassou, B., Xanthoulis, D., Bouaziz, A., Ruelle, P., and Mailhol, J. C. 2012. "Effect of Water Stress on Growth, Water Consumption and Yield of Silage Maize under Flood Irrigation in a Semi-arid Climate of Tadla (Morocco)." Biotechnologie Agronomie Soci. Environnement 16 (4): 1-10.

[16] Muahammad Aamir Aqbal and Mian Munir Ahmad. 2015. "Boosting Spring Planted Irrigated Maize (Zea Mays L.) Grain Yield with Planting Patterns Adjustment." American-European Journal of Agricultural and Environmental Sciences $15 \quad$ (3): 315-319. DOI:10.5829/idosi.aejaes.2015.15.3.12516.

[17] Malaviarachchi, M. A. P. W. K., Karunarathne, K. M., and Jayawardane, S. N. 2007. "Influence of Plant Density on Yield of Hybrid Maize (Zea Mays L.) under Supplementary Irrigation.” J. Agric. Sci. 3 (2): 58-66.

[18] Badu, A., and Lun, B. A. F. 2010. "Grain Yield Response of Normal and Quality Protein Maize Cultivars in Stress and Non-stress Environments." Agron. J. 102: 381-394.

[19] Agba O. A., Ubi B. E., Abam, P., Ogbechi, J., Akeh, M., and Odey, S. O. et al. 2012. "Evaluation of Agronomic Performance of Maize (Zea Mays L.) under Different Rates of Poultry Manure Pplication in an Ultisol of Ububra, Cross River State, Nigeria." International Journal of Agriculture and Forestry 2 (4): 138-144.

[20] Makinde E. A., and Ayoola, O. T. 2010. "Growt, Yield and NPK Uptake by Maize with Complementary Organic and Inorganic Fertilizers." Africal Journal of Food, Agriculture, Nutrition and Development (AJFAND) 10 (3): 2204-2217.

[21] Alabi, S.O., Kling, J. G., Ado, S. G., Uyorbisere, E. O., and Ajala, S. O. 2003. "Progress in Breeding for Low Nitrogen Stress in Maize in the Northern Guinea 


\section{Rates in Embu County, Kenya}

Savanna.” International Journal of Agricultural Research 7: 1-16.

[22] Havlin, J. L., Beaton, J. D., Tisdale, S. L., and Nelson, W. L. 2007. Soil Fertility and Fertilizers, 7th Ed.. New Delhi: Pearson Education.

[23] Undie U. L., Uwah, D. F., and Attoe, E. E. 2012. "Growth and Development of Late Season Maize/Sorghum Intercropping in Response to Nitrogen and Crop Arrangement in the Forest Agroecology of Southern Nigeria." International Journal of Agricultural Research 7: 1-16.

[24] Muahammad, A. A., Zahoor, A., Quiser, M., Sher, A., and Mian, M. A. 2015. "Optimizing Nitrogen Level to Improve Growth and Yield of Spring Planted Irrigated Maize (Zea Mays L.)." Journal of Advanced Botany and Zoology 2 (3): 1-4. 